\title{
PERILAKU BULLYING SISWA DITINJAU DARI PERSEPSI POLA ASUH OTORITER DAN KEMAMPUAN BEREMPATI
}

\author{
Sri Suparwi \\ Sekolah Tinggi Agama Islam Negeri Salatiga \\ Supparwi@yaboo.com
}

\begin{abstract}
The purpose of this research is finding the correlation between authoritative teaching and empathy toward bullying in the students of SMP Mubammadiyah in Salatiga. The subjects of this research are among 115 students of the third grade. The finding shows that there is a positive correlation among authoritative teaching and empathy toward bullying.
\end{abstract}

Keywords: Bullying, Authoritative perception, Empathy.

\begin{abstract}
Abstrak
Penelitian ini bertujuan untuk mengetabui bubungan antara persepsi pola asub otoriter dan kemampuan berempati dengan perilaku bullying pada siswa SMP Mubammadiyah di Salatiga. Subyek pada penelitian ini adalah siswa kelas 3 SMP Muhammadiyah Salatiga berjumlah 115 orang. Hasil penelitian menunjukkan babwa terdapat bubungan yang positif dan sangat signifikan antara persepsi pola asub otoriter dan kemampuan berempati dengan perilaku bullying $(R=0,473, F=16,161 ; p=0,000<$ 0,01, $\operatorname{dan} R^{2}=0,224$ )
\end{abstract}

Kata kunci: Perilaku Bullying, Persepsi pola asuh otoriter, Kemampuan berempati. 


\section{Pendahuluan}

Usia SMP merupakan masa transisi antara masa anak-anak dan masa dewasa, dimana siswa akan mengalami perubahan perkembangan yang sangat pesat baik secara biologis, kognitif maupun sosio-emosional. Sulitnya siswa melakukan adaptasi terhadap lingkungan social, menyebabkan siswa cenderung memiliki risiko tinggi terhadap terjadinya kenakalan dan kekerasan baik sebagai korban maupun sebagai pelaku ( Santrock, 2007).

Beberapa tahun belakangan ini banyak terjadi praktik school bullying. Wiyani (2012) School Bullying adalah perilaku agresif yang dilakukan berulang-ulang oleh seseorang/sekelompok siswa yang memiliki kekuasaan terhadap siswa-siswi yang lebih lemah dengan tujuan menyakiti. School bullying muncul akibat adanya pelanggaran yang disertai dengan penghukuman, terutama fisik, akibat buruknya system dan kebijakan pendidikan yang berlaku yaitu muatan kurikulum yang hanya mengandalkan kemampuan aspek kognitif dan mengabaikan pendidikan dengan kemampuan afektif. Disamping itu, school bullying juga dipengaruhi perkembangan kehidupan masyarakat yang mengalami moving faster sehingga menimbulkan sikap instant solution (jalan pintas) dan kekerasan yang dipengaruhi oleh latar belakang social ekonomi pelaku.

Praktik School bullying sebagai bentuk kekerasan di institusi pendidikan bisa dilakukan antar teman, antar siswa, antar geng di sekolah, kakak kelas (senior) bahkan guru. Lokasi kejadiannya mulai dari ruang kelas, toilet, kantin, halaman, pintu gerbang bahkan di luar pagar sekolah. Akibatnya sekolah bukan lagi menjadi tempat yang menyenangkan bagi siswa, melainkan justru menjadi neraka, tempat yang menakutkan dan membuat trauma siswa. Korban school bullying tidak hanya menderita ketakutan di sekolah saja, bahkan banyak kasus school bullying yang mengakibatkan korbannya meninggal (Sejiwa, 2008).

Praktik school bullying sangat memprihatinkan bagi pendidik, orang tua dan masyarakat. Sekolah yang seharusnya menjadi tempat bagi anak untuk menimba ilmu dan membantu membentuk karakter pribadi yang positif ternyata malah menjadi tempat tumbuhnya praktik-praktik bullying. School bullying memberi ba- 
nyak sekali dampak buruk kepada siswa yang menjadi korban, yang secara structural menyebabkan kemunduran pendidikan nasional. Oleh karena itu school bullying menjadi masalah fundamental untuk segera ditangani.

Persepsi pola asuh otoriter merupakan salah satu faktor eksternal yang diduga mempengaruhi perilaku bullying. Pola asuh merupakan pola interaksi antara orang tua dan anak yaitu bagaimana cara sikap atau perilaku orang tua saat berinteraksi dengan anak, termasuk cara penerapan aturan, mengajarkan nilai/norma, memberikan perhatian dan kasih sayang serta menunjukkan sikap dan perilaku baik sehingga dijadikan panutan bagi anaknya (Dariyo, 2004). Pola asuh menurut agama adalah cara memperlakukan anak sesuai dengan ajaran agama berarti memahami anak dari berbagai aspek dan memahami anak dengan memberikan pola asuh yang baik, menjaga anak dan harta anak yatim, menerima, memberi perlindungan, pemeliharaan, perawatan dan kasih sayang sebaikbaiknya (QS Al Baqoroh: 220).

Pola asuh otoriter orangtua merupakan salah satu bentuk pola asuh yang menerapkan kontrol yang sangat ketat terhadap anak, selalu mengekang, menghukum, menilai sikap dan perilaku anak dengan standar mutlak, anak harus patuh kepada orangtua (Baumrind, dalam Hetherington \& Parke, 1999; Berns, 2007). Siswa mempersepsikan orangtuanya otoriter jika remaja tersebut merasa orangtuanya sangat mengekang, ketat dalam mengontrol, anak merasa harus selalu patuh kepada aturan orangtua, dan orangtua tidak mau mendengarkan pendapatnya. Pola asuh otoriter orangtua ini akan memberikan dampak kepada pola interaksi siswa dengan teman-temannya, salah satunya adalah siswa cenderung melakukan bullying terhadap temannya.

Georgiou (2008) Pola asuh otoriter cenderung mengakibatkan anak berperilaku bullying. Anak belajar melakukan agresif kepada orang yang lebih lemah dari melihat interaksi sehari-hari dalam keluarganya. Pontzer (2010) Pola asuh yang keras, mengabaikan, ketidakhadiran, penolakan, kurangnya kasih sayang yang positif, dan tidak diajarkan untuk menunjukkan perilaku yang tepat berkaitan dengan perilaku bullying. Orangtua yang berinteraksi dengan anaknya secara bermusuhan, dingin, acuh tak acuh, tidak konsisten, 
dan mengecewakan anaknya akan mendorong anak untuk berinteraksi dengan orang lain dengan cara yang sama. Anak memperlakukan orang lain dengan buruk sehingga meningkatkan kecenderungan perilaku bullying pada anak.

Kemampuan siswa untuk berempati dengan orang lain juga berhubungan dengan perilaku bullying (Jacobs,2006). Empati merupakan suatu respon emosi ketika seseorang merasa seolaholah mengalami sendiri pengalaman emosi yang dialami oleh orang lain dan kemampuan untuk berbagi perasaan dengan orang lain (Knight, 1989). Pontzer (2010) kurangnya kemampuan untuk berempati kepada orang lain berkaitan dengan kecenderungan perilaku bullying. Santrock (2007) kurangnya kemampuan berempati mengakibatkan seseorang menjadi tidak mampu memahami rasa sakit yang diakibatkan oleh perbuatannya dan tidak memiliki rasa kasihan terhadap korban. Jolliffe dan Farrington (2006) Rendahnya kemampuan berempati membuat seseorang kurang mampu merespon tekanan dan ketidaknyamanan yang dialami oleh orang lain, karena orang yang rendah empatinya tidak mampu memahami pengalaman emosi yang dialami oleh orang lain. Rendahnya kemampuan berempati membuat seseorang tidak mampu menghubungkan perilaku anti sosial yang dilakukan dengan reaksi emosi orang lain.

Berdasarkan kenyataan di atas, maka perlu kiranya diadakan studi lebih lanjut tentang hubungan antara persepsi pola asuh otoriter dan kemampuan berempati dengan perilaku bullying. Hal ini dilakukan karena hasil penelitian menunjukkan bahwa persepsi pola asuh otoriter dan kemampuan berempati berkorelasi positif dan sangat signifikan dengan perlaku bullying pada siswa SMP Muhammadiyah di Salatiga.

\section{Perilaku Bullying}

Ken Rigby (2008) mengartikan bullying sebagai suatu hasrat untuk menyakiti yang diperlihatkan ke dalam aksi dan menyebabkan seseorang menderita. Aksi ini dilakukan secara langsung oleh seseorang atau kelompok yang lebih kuat, tidak bertanggung jawab, biasanya berulang-ulang dan dilakukan dengan perasaan senang. Eisenberg (2006) mendefinisikan bullying merujuk pada perilaku 
agresif verbal dan fisik yang dilakukan secara terus menerus dan langsung terhadap individu ditujukan kepada teman sebaya sebagai korban. Papalia, Olds dan Feldman (2007) bullying merupakan perilaku agresi yang disengaja dan berlangsung secara terus-menerus yang ditujukan pada individu yang sudah menjadi incaran atau korban. Istilah bullying atau victimization (Olweus, 2003) digunakan ketika seseorang secara terang-terangan melakukan tindakan negatif terhadap satu orang atau sekelompok orang secara berulang kali. Tindakan negatif yang dimaksud yaitu ketika seseorang secara sengaja menimbulkan rasa sakit atau ketidaknyamanan terhadap orang lain, berupa tindakan fisik, kata-kata, atau cara lain misalnya raut wajah atau gerakan tubuh, menyebarkan rumor, dan mengeluarkan secara sengaja dari kelompok. Pada bullying, terjadi ketidakseimbangan kekuatan dalam hubungan, sehingga siswa yang mendapatkan tindakan negatif kesulitan dalam mempertahankan dirinya dan tanpa pengharapan melawan siswa yang melakukan kekerasan. Target bullying secara aktual memiliki fisik yang lemah, atau mentalnya lemah dibandingkan pelaku, atau adanya perbedaan jumlah, dimana beberapa siswa mengganggu satu orang korban. Olweus (2003) menemukan beberapa ciri perilaku bullying antara lain: (1). adanya perilaku agresif dan negative yang sengaja dilakukan, (2). dilakukan secara berulang kali, (3). Adanya ketidakseimbangan kekuatan, dan (4). Mengakibatkan dampak negatif bagi korban (Houbre, dkk., 2010).

Berdasarkan penjelasan di atas dapat disimpulkan bahwa perilaku bullying adalah perilaku agresif yang sengaja dilakukan oleh seseorang baik secara fisik, verbal, maupun psikologis yang dilakukan secara berulang-ulang sehingga mengakibatkan dampak negatif bagi korban.

\section{Faktor-faktor yang Mempengaruhi Perilaku Bullying}

Pontzter (2010) Perilaku bullying siswa disebabkan karena persepsi siswa terhadap pola asuh otoriter orang tua. Pola asuh otoriter orangtua ini akan memberikan dampak kepada pola interaksi siswa dengan teman-temannya, salah satunya adalah siswa cenderung melakukan bullying terhadap temannya. Georgiou (2008) Anak belajar melakukan agresif kepada orang yang lebih lemah dari 
melihat interaksi sehari-hari dalam keluarganya. Pola asuh otoriter cenderung mengakibatkan anak berperilaku bullying.

Kemampuan berempati juga merupakan factor yang mempengaruhi siswa melakukan perilaku bullying (Jacobs, 2006). Kurangnya kemampuan berempati mengakibatkan seseorang menjadi tidak mampu memahami rasa sakit yang diakibatkan oleh perbuatannya dan tidak memiliki rasa kasihan terhadap korban (Santrock, 2007). Jolliffe dan Farrington (2006) Rendahnya empati membuat seseorang kurang mampu merespon tekanan dan ketidaknyamanan yang dialami oleh orang lain, karena orang yang rendah empatinya tidak mampu memahami pengalaman emosi yang dialami oleh orang lain. Orang yang kurang empati tidak mampu menghubungkan perilaku anti sosial yang dilakukan dengan reaksi emosi orang lain.

\section{Persepsi Pola Asuh Otoriter}

VandenBos (2007) persepsi adalah aktivitas mengenali, mengamati, dan membedakan dengan menggunakan indera sehingga seseorang menyadari suatu objek, hubungan dan peristiwa. Aktivitas tersebut membuat individu mampu mengatur dan menginterpretasi stimulusstimulus yang diterima menjadi suatu pengetahuan yang bermakna. DeVito (1995) persepsi merupakan suatu proses aktif untuk mengamati objek, kejadian, dan orang lain melalui indra penglihatan, penciuman, pendengaran, dan peraba. Lebih lanjut DeVito (1995) mengemukan bahwa persepsi adalah proses kognitif yang meliputi penerimaan, pengorganisasian, dan penafsiran terhadap suatu objek atau lingkungan yang diterima anak. Penerimaan, pengorganisasian, dan penafsiran yang diterima sangat tergantung pada pengalaman masa lalu yang diperoleh melalui proses belajar, yang menentukan sikap terhadap suatu objek atau mempengaruhi perilaku. Menurut Walgito (2002) persepsi menunjukkan adanya suatu aktivitas mengindera, dan berfungsi menginterpretasi dan memberikan penilaian terhadap objek-objek fisik maupun sosial. Proses persepsi dimulai pada waktu stimulus mengenai indra. Stimulus ini kemudian diteruskan oleh saraf sensoris ke pusat susunan saraf yaitu otak. Stenberg (1999) menjelaskan persepsi lebih spesifik yaitu persepsi interpersonal. Persepsi interpersonal merupakan penilaian individu tentang 
karakteristik orang lain yang berinteraksi dengannya. Melalui interaksi ini terjadi proses penilaian tentang karakteristik dari masingmasing individu yang dapat menimbulkan rasa senang ataupun tidak senang dari kedua belah pihak.

Baumrind (dalam Hetherington \& Parke, 1999) pola asuh otoriter merupakan pola asuh yang menekankan kontrol dan kepatuhan anak. Orangtua yang otoriter memperlakukan anaknya dengan keras, tidak responsif, kurang hangat, kaku, orangtua cenderung menggunakan metode kekuasan yang tegas dalam mengontrol anaknya. Mereka membuat anak menyesuaikan diri dengan serangkaian standar perilaku dan menghukum anak secara membabi buta dan keras atas pelanggaran yang dilakukan oleh anak.

Persepsi pola asuh otoriter adalah penilaian dan interpretasi terhadap serangkaian tindakan orangtua (ayah dan ibu) dalam berinteraksi dengan anaknya yang memiliki ciri-ciri penerapan disiplin yang keras, kaku, mengontrol anak secara berlebihan, menuntut anak melakukan sesuatu tanpa berdiskusi dan tanpa memberikan penjelasan, menuntut kepatuhan anak, keputusan berdasarkan keinginan dan keyakinan orangtua, orangtua menolak untuk merubah ide dan perilaku mereka, sering memberikan kritik dan hukuman, dan cenderung tidak menyenangi perilaku anaknya.

\section{Jenis-Jenis Pola Asuh Orang Tua}

Ada 4 Jenis pola asuh orang tua yaitu : pola asuh otoriter, otoritatif, permisif, dan pola asuh tidak terlibat (Baumrind (dalam Hetherington \& Parke, 1999; Berns, 2007; Papalia, dkk., 2008) dan Maccoby \& Martin (dalam Berns, 2007).

\section{Pola Asub Otoriter}

Orangtua yang otoriter memperlakukan anaknya dengan keras, tidak responsif, kurang hangat, kaku, orangtua cenderung menggunakan metode kekuasan yang tegas dalam mengontrol anaknya. Mereka membuat anak menyesuaikan diri dengan serangkaian standar perilaku dan menghukum anak secara membabi buta dan keras atas pelanggaran yang dilakukan oleh anak. 


\section{Pola Asub Autoritatif}

Pola asuh autoritatif memadukan penghargaan terhadap individualitas anak dengan upaya membentuk nilai sosial secara perlahan. Orangtua yang menerapkan pola asuh autoritatif akan memperlakukan anaknya dengan penuh kehangatan, responsif, orangtua terlibat secara efektif, dan orangtua memberikan batasan yang tepat dan pengharapan yang sewajarnya atas perkembangan perilaku anak mereka. Orangtua yang autoritatif memiliki keyakinan akan kemampuan mereka dalam membimbing anak-anaknya, menghormati kemandirian anak dalam mengambil keputusan, ketertarikan, pendapat, dan kepribadian anak. Orangtua mencintai dan menerima anaknya, tetapi juga menuntut perilaku yang baik dari anaknya, konsisten dalam mempertahankan standar, dan memberikan hukuman secara bijaksana terhadap anaknya dalam hubungan yang tetap hangat dengan anaknya.

\section{Pola Asub Permisif}

Pola asuh permisif merupakan pola asuh yang menekankan ekspresi diri dan regulasi diri. Orangtua yang menerapkan pola asuh permisif terlihat memiliki peran orangtua yang lemah dan orangtua menerapkan disiplin kepada anaknya secara tidak konsisten dan mendorong anak untuk mengekspresikan keinginannya secara bebas. Orangtua membiarkan anaknya mengontrol kegiatannya sendiri dan hanya memberikan sedikit tuntutan kepada anaknya. Orangtua berkonsultasi dengan anaknya tentang keputusan yang akan diambilnya dan jarang menghukum, hangat, dan tidak mengontrol.

\section{Pola Asub Tidak Terlibat}

Pola asuh tidak terlibat (uninvolved parenting), memperlihatkan sikap orangtua yang acuh tak acuh dan mengabaikan anaknya, orangtua terlihat lebih memusatkan perhatian kepada kebutuhannya sendiri daripada kebutuhan anaknya.

\section{Kemampuan Berempati}

Empati adalah kemampuan untuk menempatkan diri pada posisi orang lain dan merasakan apa yang dirasakan oleh orang tersebut 
(Papalia, dkk., 2007). Hoffman (1984) empati sebagai respon afektif seolah-olah mengalami sendiri pengalaman emosi orang lain. Santrock (2007) empati merupakn suatu reaksi terhadap perasaan orang lain dengan respon emosi yang hampir sama dengan perasaan orang tersebut. Lebih lanjut dijelaskan bahwa empati merupakan suatu kemampuan untuk memahami perasaan, kekhawatiran, dan musibah yang dialami orang lain. Empati juga diartikan sebagai melihat dunia melalui mata orang lain, mendengarkan sebagaimana mereka mendengar, merasakan dan mengalami dunia internal mereka (Borba, 2001; Snyder dan Lopez, 2007; Subandi, 2002). Rogers (1980) mengatakan bahwa berempati kepada orang lain memiliki makna masuk ke dunia pribadi orang lain, dan secara menyeluruh berada di sana. Orang yang memiliki empati menjadi sensitif, dari waktu ke waktu, mengubah makna-makna yang dirasakan orang lain, sensitif terhadap rasa takut atau kemarahan, kebingungan, atau apapun yang orang lain tersebut alami. Empati adalah respon emosi dimana seseorang merasa seolah-olah mengalami sendiri pengalaman emosi yang dialami oleh orang lain dan kemampuan untuk berbagi perasaan dengan orang lain (Knight, 1989). Empati yang baik adalah suatu kekuatan untuk memasuki pribadi orang lain, mengimajinasikan pengalaman orang lain (Knight, 1989), dan mengandung keterlibatan hati (Snyder \& Lopez, 2007). Bavolek (2007) mendefinisikan empati sebagai suatu respon empatik guna memposisikan diri pada posisi orang lain sehingga perasaan yang dirasakan tidak hanya sekedar merasakan secara emosional tetapi juga mampu memberikan motivasi kepada orang yang bersangkutan. Rousseau (2004) mendefinisikan empati sebagai kemampuan untuk memahami pengalaman pribadi dan perasaanperasaan orang lain, kapasitas untuk melihat dari perspektif orang lain, kapasitas untuk masuk ke dalam pengalaman dan perasaan orang lain. Empati juga dapat diartikan sebagai kemampuan untuk menempatkan diri dalam pikiran dan perasaan orang lain tanpa harus terlibat dalam pikiran dan perasaan orang lain tersebut (Koestner, Weinberger, \& Franz, 1990). Selain itu, empati juga didefinisikan sebagai kemampuan untuk memahami dan menghubungkan terhadap pengalaman kognitif dan emosi orang lain (Worthington \& Wade dalam Hodgson \& Wertheim, 2007 ). Empati 
mengasah kepekaan seseorang terhadap sudut pandang dan pendapat orang lain. Empati berperan meningkatkan sifat kemanusiaan, keadaban, dan moralitas. Empati merupakan emosi yang mengusik hati nurani seseorang ketika melihat kesusahan orang lain. Empati membuat seseorang dapat menunjukkan toleransi dan kasih sayang, memahami kebutuhan orang lain, serta mau membantu orang yang sedang kesulitan. Individu yang belajar berempati akan jauh lebih pengertian dan penuh kepedulian, dan biasanya lebih mampu mengendalikan kemarahan (Borba, 2001). Empati ini tidak hanya meningkatkan perilaku prososial, tetapi juga mengurangi agresivitas dan meningakatkan perkembangan moral (Gibbs, 2003).

Berdasarkan beberapa definisi empati di atas dapat disimpulkan bahwa kemampuan berempati merupakan kemampuan untuk memahami berbagai macam perasaan orang lain, dan seolah-olah mengalami sendiri perasaan dan pengalaman emosi orang lain tersebut, serta melihat dari sudut pandang orang lain.

\section{Aspek-Aspek Empati}

Menurut Davis (1983); Brehm dan Kasim (1993); Håkansson dan Montgomery (2003); Markstrom, Huey, Stiles, dan Krause (2009); Kerem, Fishman, dan Josselson (2001); Hojat (2001); Taufik, 2012) empati memiliki dua aspek yaitu:

a. Aspek kognitif

Aspek kognitif empati merupakan kemampuan intelektual untuk mengidentifikasi, memahami serta menyimpulkan pikiran dan perasaan berdasarkan perspektif orang lain. Hojat (2001) menyatakan bahwa aktivitas dari aspek kognitif adalah perspective taking dan role taking. Pada empati kognitif ini terdapat respon mental yang khas yaitu pertimbangan dan penilaian.

b. Aspek emosi

Aspek emosi atau afeksi diartikan sebagai kemampuan untuk merasakan situasi dan keadaan emosi yang dialami orang lain, dan responnya hampir sama dengan situasi dan keadaan emosi orang lain tersebut, serta seolah-olah mengalami seperti yang dialami oleh orang tersebut. Hojat (2001) mengungkapkan bahwa pada empati emosi ini ditandai dengan respon spontanitas 
dan menggerakkan. Selain kemampuan untuk memahami perasaan dan perpektif orang lain, empati ini juga meliputi kemampuan untuk mengkomunikasikan perasaan dan pemahaman empati kepada orang lain secara verbal dan non verbal (Bavolek, 2007).

Ada beberapa penelitian sebelumnya yang relevan dengan penelitian ini antara lain:

Ardianta (2010) upaya untuk menanggulangi bullying pada remaja sebaiknya dimulai sejak dini dengan selalu menanamkan nilai-nilai keluhuran pada pribadi anak remaja, baik itu nilai keluhuran yang berasal dari agama ataupun kebudayaan adatistiadat. Nilai keluhuran seperti : kejujuran, tanggung jawab, kepedulian, cinta, empati, toleransi, kesabaran, respek, kerendahan hati, murah hati, keikhlasan, ketakwaan terhadap Tuhan Yang Maha Esa. Dari nilai-nilai keluhuran inilah seorang remaja dapat tertolong dan melepaskan dirinya dari belenggu bullying. Dan bila nilai-nilai keluhuran ini dapat hidup di tengah-tengah masyarakat, maka akan tercipta lingkungan yang harmonis, kehidupan yang lebih jernih, lebih tenang dan lebih bahagia. Islam adalah agama yang syamil (sempurna), oleh karenanya untuk menciptakan lingkungan yang bersih dan harmonis, Islam memberikan ketegasan dalam hukuman terhadap para remaja yang menjadi pelaku bullying, sebab jika tidak diberi ketegasan dalam hukuman, maka yang akan terjadi adalah kezaliman yang merajalela. Adalah sebuah tanggung jawab yang besar bagi para orang tua dan pendidik untuk memberikan pelajaran yang terbaik bagi para remaja agar menjadi pribadi yang shaleh dan bertanggung jawab, dan merupakan kesalahan terbesar ketika dalam mendidik para orang tua dan guru menganggap bahwa mendidik dengan cara kekerasan merupakan salah satu cara yang paling baik dan efektif supaya para remaja takut, taat terhadap perintah orang tua dan guru.

Ismail (2009) pengalaman keagamaan yang selalu muncul dalam diri individu menyebabkan timbulnya kontrol internal dalam dirinya sehingga dapat mencegah timbulnya perilaku-perilaku menyimpang yang dapat merugikan diri sendiri maupun orang lain. Konsep untuk menyayangi dan mencintai sesama yang terkandung 
dalam nilai-nilai agama akan dimaknai dengan baik oleh individu yang memiliki tingkat religiusitas yang baik. Hal ini akan meminimalisasi munculnya perilaku bullying seperti mengintimidasi, menyakiti orang lain dan bentuk-bentuk perilaku bullying baik fisik, verbal maupun non verbal. Menurut Ancok dan Suroso (1995) relegiusitas dapat di wujudkan dalam berbagai sisi kehidupan. Aktivitas keberagamaan bukan hanya terjadi ketika seseorang melakukan perilaku ritual atau beribadah, tetapi juga ketika melakukan aktivitas lain yang didorong oleh kekuatan akhir. Bukan hanya berkaitan dengan aktivitas yang tampak dan dapat dilihat oleh mata, tetapi juga aktivitas yang tidak tampak yang terjadi dalam hati seseorang. Karena itu keberagamaan seseorang akan meliputi berbagai macam sisi dan dimensi. Seseorang yang memiliki religiusitas yang baik akan berprilaku sesuai dengan ajaran agama sehingga dalam hubungannya sehari-hari dengan sesama cenderung untuk tidak melakukan hal yang membuat orang lain tersakiti atau dengan kata lain orang yang memiliki religiusitas yang baik tidak akan melakukan perilaku bullying karena dalam berperilaku selalu mengikuti ajaran-ajaran dalam agama.

Wiyani (2012) memaparkan gagasan peacefull school sebagai obat mujarab agar school bullying dapat berkurang bahkan dapat dihilangkan. peaceful school merupakan upaya untuk menyiapkan generasi yang cerdas nalar, cerdas emosional, dan cerdas spiritual, bukan menciptakan manusia yang kerdil, pasif, dan tidak mampu mengatasi persoalan yang dihadapi. Peaceful school (sekolah yang damai), yaitu sekolah yang kondusif bagi proses belajar mengajar yang memberikan jaminan suasana kenyamanan dan keamanan pada setiap komponen di sekolah karena adanya kasih sayang, perhatian, kepercaaan dan kebersamaan. Sekolah yang damai dapat dikategorikan menjadi 9 sudut pandang yaitu: 1). Bebas dari pertikaian dan kekerasan, 2). Ketentraman, 3). Kenyamanan dan keamanan, perhatian dan kasih sayang, 5). Kerjasama, 6) Akomodatif, 7) Ketaatan terhadap peraturan, 8) Internalisasi nilai-nilai agama,

9) Hubungan yang baik dengan masyarakat.

Hipotesis dalam penelitian ini adalah:

1. Ada hubungan antara persepsi pola asuh otoriter dengan perilaku bullying pada siswa SMP Muhammadiyah di Salatiga. 
2. Ada hubungan antara kemampuan berempati dengan perilaku bullying pada siswa SMP Muhammadiyah di Salatiga.

3. Ada hubungan antara persepsi pola asuh otoriter dan kemampuan berempati dengan perilaku bullying Pada siswa SMP Muhammadiyah di Salatiga.

\section{Metode Penelitian}

\section{Desain Penelitian}

Penelitian ini merupakan jenis penelitian kuantitatif model korelasional bertujuan untuk melihat sejauhmana variasi persepsi pola asuh otoriter dan kemampuan berempati dengan perilaku bullying. Pendekatan dalam penelitian ini menggunakan pendekatan expostfacto yaitu data dikumpulkan setelah semua peristiwa terjadi.

Variabel yang digunakan dalam penelitian ini adalah:

1. Variabel bebas : Persepsi Pola Asuh Otoriter dan Kemampuan Berempati

2. Variabel tergantung : Perilaku Bullying

\section{Definisi Operasional Variabel Penelitian}

1. Persepsi Pola Asuh Otoriter

Persepsi pola asuh otoriter yaitu penilaian siswa terhadap serangkaian tindakan orangtua dalam berinteraksi dengan siswa, yaitu penilaian terhadap interaksi yang menerapkan: kedisiplinan, kepatuhan, dan standar mutlak terhadap perilaku.

2. Kemampuan Berempati

Kemampuan berempati adalah kemampuan untuk memahami berbagai macam perasaan orang lain, dan seolah-olah mengalami sendiri perasaan dan pengalaman emosi orang lain tersebut, serta melihat dari sudut pandang orang lain.

3. Perilaku Bullying

Perilaku bullying adalah sejauhmana perilaku agresi yang dilakukan secara sengaja oleh individu atau kelompok teman sebaya yang lebih kuat terhadap individu atau kelompok teman sebaya yang lebih lemah, baik secara fisik, verbal, atau psikologis yang 
dilakukan secara berulang-ulang, serta mengakibatkan dampak negatif bagi korban.

\section{Populasi dan Sampel}

Populasi dalam penelitian ini adalah siswa SMP Muhammadiyah di Salatiga yang berjumlah 225, sedangkan sampel dalam penelitian ini adalah seluruh siswa kelas 3 SMP Muhamadiyah Salatiga berjumlah 115 siswa. Teknik sampling yang digunakan adalah purposive sampling dengan kreteria siswa kelas 3 berusia $12-15$ tahun. Alasan memilih siswa Sekolah Menengah Pertama sebagai subjek penelitian adalah karena bullying lebih banyak terjadi pada sekolah tingkat menengah dibandingkan dengan sekolah tingkat atas (Cobb, 2007).

\section{Teknik Pengumpulan Data}

Data penelitian dikumpulkan melalui teknik interview dan teknik pengukuran skala.

1. Interview dilakukan terhadap beberapa siswa, guru bimbingan dan konseling (BK) dan bagian kesiswaan untuk memperoleh data awal tentang perilaku bullying siswa SMP Muhammadiyah di Salatiga.

2. Pengukuran Skala dilakukan untuk memperoleh data persepsi pola asuh otoriter, kemampuan berempati dan perilaku bullying. Data ketiga variabel itu diperoleh melalui pengadministrasian skala yaitu skala persepsi pola asuh otoriter, skala kemampuan berempati dan skala perilaku bullying .

\section{Teknik Analisis Data}

Analisis data adalah cara untuk mengolah dan menganalisis data yang telah terkumpul sehingga mendapat kesimpulan dari penelitian yang telah dilakukan. Analisis data yang digunakan dalam penelitian ini adalah menggunakan analisis regresi linear berganda. Analisis regresi linear berganda digunakan untuk melihat hubungan antara dua variabel bebas dengan satu variabel tergantung (Sarwono, 2006). Analisis statistik pada penelitian ini dibantu dengan menggunakan program SPSS versi 16.0 for windows. 


\section{Hasil Kategorisasi Skala Penelitian}

1. Skala PPAO

Hasil kategorisasi pada skala persepsi pola asuh otoriter memiliki mean empirik yang lebih kecil dari mean hipotetik. Persepsi pola asuh otoriter pada subjek dalam penelitian ini cenderung mengelompok pada kategori sedang sebanyak 88 siswa $(76,52 \%)$ dan kategori tinggi sebanyak 27 subyek (23,48\%). Hal ini menunjukkan bahwa siswa memberikan persepsi terhadap pola asuh orangtuanya cenderung ke tingkat otoriter sedang sampai tinggi.

2. Skala Kemampuan Berempati

Hasil kategorisasi pada skala kemampuan berempati memiliki mean empirik yang lebih kecil dari mean hipotetik. Kemampuan berempati pada subjek dalam penelitian ini mengelompok pada kategorisasi rendah sebesar 47,8\%, kategorisasi sedang sebesar 46,95\%, sedangkan kategorisasi tinggi sebesar 5,22\%.

3. Skala Perilaku Bullying

Hasil kategorisasi pada skala perilaku bullying memiliki mean empirik yang lebih besar dari mean hipotetik. Berdasarkan kriteria kategorisasi diperoleh 38 subjek (33,04\%) memiliki perilaku bullying tinggi, dan 44 subjek ( $38,26 \%)$ memiliki perilaku bullying sedang, dan 33 siswa (28,69 \%) memiliki perilaku bullying rendah. Perilaku bullying siswa cenderung merata dari rendah, sedang dan tinggi.

\section{Anallisis}

Berdasarkan analisis regresi dapat dibuat persamaan regresi sebagai berikut :

$$
\mathrm{Y}=36.000+0,441 \mathrm{X} 1+0,540 \mathrm{X} 2
$$

Setiap ada kenaikan nilai persepsi pola asuh otoriter sebesar $\alpha=0,441$ dan kemampuan berempati sebesar $\alpha=0,540$ akan mempengaruhi perilaku bullying siswa (Triton, 2006). 
Penelitian ini bertujuan menguji hubungan antara persepsi pola asuh otoriter dan kemampuan berempati dengan perilaku bullying. Hasil uji hipotesis dengan analisis regresi ganda menunjukkan bahwa persepsi pola asuh otoriter dan kemampuan berempati memiliki hubungan yang positif dan signifikan dengan perilaku bullying pada siswa SMP Muhammadiyah di Salatiga ditunjukkan dengan koefisien korelasi 0,473 dengan koefisien variansi $\mathrm{F}=16,161$ dan $\mathrm{p}=0,000(\mathrm{p}<0,001)$ serta koefisien determinasi $\mathrm{R}^{2}=0,224$. Penelitian ini menjelaskan bahwa perilaku bullying dapat diprediksi melalui variable persepsi pola asuh otoriter dan kemampuan berempati. Sumbangan efektif dari persepsi pola asuh otoriter dan kemampuan berempati dengan perilaku bullying sebesar 22,4\%, sedangkan 77,6\% sisanya dipengaruhi oleh factor lain yang tidak menjadi focus dalam penelitian ini. Hasil analisis secara parsial menunjukkan bahwasanya variable persepsi pola asuh otoriter memberikan pengaruh lebih besar terhadap perilaku bullying dibandingkan dengan variable kemampuan berempati, dengan sumbangan partial pengaruh persepsi pola asuh otoriter sebesar 20,8\%, sedangkan sumbangan partial pengaruh kemampuan berempati terhadap perilaku bullying sebesar 2,6\%. Hal ini menunjukkan bahwa siswa merasa persepsi pola asuh otoriter dianggap lebih mempengaruhi perilaku bullying secara langsung dibandingkan dengan kemampuan berempati.

Penelitian ini mendukung hasil-hasil penelitian sebelumnya diantaranya penelitian yang dilakukan oleh Knafo (2003) bahwa perilaku ayah yang otoriter cenderung berhubungan dengan perilaku bullying pada remaja. Remaja yang memiliki ayah yang otoriter cenderung melakukan kekerasan terhadap orang lain, remaja cenderung mempersepsikan temannya sama dengan ayahnya, dan merasa lebih nyaman ketika mampu untuk lebih kuat dan menguasai temannya. Senada dengan hasil penelitian Lee (2009) bahwa perilaku otoriter orangtua merupakan prediktor perilaku bullying di sekolah melalui perilaku menekan teman sebaya dan rasa tidak harmonis di sekolah. Anak yang diasuh secara otoriter cenderung melakukan penekanan terhadap temannya, selain itu mereka merasa kurang harmonis di sekolah. Lebih lanjut dijelaskan Lee (2009) anak mempelajari perilaku dari pola interaksi dengan 
orangtuanya. Orangtua yang otoriter kadang-kadang merespon perilaku agresif anaknya dengan memukul pantat anaknya. Pemberian hukuman secara agresif kepada anak mengakibatkan anak meniru perilaku tersebut. Sebagai akibatnya, anak meniru perilaku agresif orangtuanya dan mempraktekkannya kepada teman sebayanya. Papalia, dkk. (2007) remaja berkecenderungan lebih besar untuk melakukan kekerasan jika mereka memiliki model panutan untuk melakukan kekerasan. Sama halnya dengan orangtua otoriter yang cenderung memberikan hukuman secara agresif membuat anak cenderung meniru perilaku agresif orangtuanya. Pola asuh orangtua yang otoriter dan perkembangan emosi remaja yang belum stabil membuat remaja belum mampu memikirkan dampak dari peniruan perilaku negatif orangtuanya karena remaja masih dikuasai oleh emosi dalam berpikir dan berperilaku. Adanya proses meniru perilaku orangtua dan perkembangan emosi yang belum stabil membuat remaja belum mampu mengatur pikiran, perasaan, dan perilakunya sehingga remaja cenderung untuk melakukan bullying terhadap orang lain. Bandura (dalam Rice \& Dolgin, 2002) menjelaskan bahwa anak belajar melakukan perilaku agresif (termasuk bullying) dari belajar meniru lingkungannya. Anak yang melihat orangtuanya melakukan perilaku agresif akan menirunya dan mempraktekkannya ketika berinteraksi dengan temannya di luar rumah. Orangtua yang membiarkan perilaku agresif anaknya atau memberikan hukuman atas perilaku agresif anaknya, misalnya dengan hukuman fisik, pengucilan, mencabut hak-hak anak, maka akan membuat anak menjadi lebih agresif.

Selain persepsi pola asuh otoriter, ada factor lain yang terbukti mempengaruhi perilaku bullying yaitu kemampuan berempati. Hal tersebut didukung penelitian Wahyuni (2010) bahwa rendahnya kemampuan berempati berkorelasi dengan kecenderungan berperilaku bullying pada remaja. Hasil penelitian ini mendukung penelitian Jolliffe dan Farrington (2006) bahwa ada hubungan antara rendahnya empati dengan perilaku bullying baik pada remaja perempuan maupun pada remaja laki-laki. Gini, Albiero, Benelli, dan Altoe (2007) bahwa ada hubungan negatif antara kecenderungan perilaku bullying dengan empati. Semakin tinggi kecenderungan perilaku bullying, maka semakin rendah kemampuan berempati pada subjek. 
Hasil penelitian Warden dan Mackinnon (2003) bahwa anak yang menjadi pelaku bullying atau yang menjadi korban bullying terlihat kurang memiliki empati dibanding dengan anak yang berperilaku prososial. Anak yang prososial terlihat lebih populer, memiliki kemampuan berempati yang tinggi, memiliki kemampuan yang baik dalam merespon situasi sosial yang sulit, dan lebih menyadari akibat dari perilaku negatifnya dibanding dengan anak yang berperilaku bullying. Rock (2004) menambahkan bahwa pengalaman masa lalu anak sebagai korban bullying juga mempengaruhi terhadap perkembangan empati pada anak. Anak yang pernah mengalami perilaku agresif dari teman-temannya dan memiliki teman yang kurang mampu memahami perasaannya membuat anak juga cenderung melakukan perilaku agresif terhadap orang lain. Anak menjadi kurang mampu memahami perasaan orang lain khususnya korban bullying. Caravita dan Blasio (2009) juga menemukan bahwa kemampuan berempati pada remaja laki-laki berhubungan dengan kecenderungan berperilaku bullying, remaja laki-laki yang kurang mampu untuk berempati kepada orang lain cenderung melakukan bullying.

Dari uraian di atas dapat disimpulkan bahwa persepsi siswa tentang pola asuh otoriter dan kemampuan berempati secara simultan memiliki hubungan yang positif dan sangat signifikan dengan perilaku bullying pada siswa SMP Muhammadiyah di Salatiga. Mengingat sumbangan efektif penelitian ini hanya 22,4 persen, maka peneliti selanjutnya diharapkan mampu mengungkap predictorprediktor lain yang berpengaruh terhadap perilaku bullying baik factor internal maupun faktor eksternal.

\section{Kesimpulan}

Berdasarkan hasil penelitian dan analisis data yang dilakukan terhadap temuan di lapangan maka dapat disimpulkan bahwa persepsi pola asuh otoriter dan kemampuan berempati secara bersama-sama memiliki hubungan yang positif dan sangat signifikan dengan perilaku bullying dengan sumbangan efektif sebesar 22,6 persen sedangkan 77,4 persen sisanya dipengaruhi oleh prediktorprediktor lain yang tidak menjadi fokus dalam penelitian ini. 
Variabel persepsi pola asuh otoriter memiliki pengaruh 20,2 persen lebih tinggi dibandingkan dengan kemampuan berempati yang memiliki pengaruh 2,4 persen.

\section{Daftar Pustaka}

Ardianta, J. 2010. Prinsip-prinsip Islam dalam menanggulangi Bullying., (Tesis). UIN Sunan Kalijaga

Berns, R.M. 2007. Child, family, school, community: socialization and support. Seventh Edition: Kanada: Thomson Wadsworth.

Borba, M. 2001. Building moral intelligence: the seven essential virtues that teach kids to do the right thing. San Francisco: Jossey-Bass.

Brehm, S., \& Kassin, 1993. Social psychology. Boston: Hougton Mifflin Company.

Cobb, N.J. 2007. Adolescence: continuity, change, and diversity. New York: McGraw-Hill.

Davis, M. H. 1983. Measuring individual differences in empathy: evidence for a multidimensional approach. Journal of Personality and Social Psyachology, 44 (1), 113-126.

DeVito, J.A. 1995. The interpersonal communication book. New York: Harper Collins College Publisher.

Eisenberg, N. 2006. Empathy-related responding and prosocial behaviour. Empathy and Fairness. John Wiley \& Sons Ltd.

Georgiou, S.N. 2008. Parental style and child bullying and victimization experiences at school. Social Psychology Education, 11, 213-227.

Gibbs, J.C. 2003. Moral development and reality. London: Sage Publication, Inc.

Hetherington, E.M. \& Parke, R.D. 1999. Child psychology: a contemporary viewpoint. Fifth Edition. USA: McGraw-Hill College.

Hojat, M., Mangione, S., Nasca, T.J., Cohen, M.J.M., Gonnella, J.S., Erdmann, J.B., Veloski, J., \& Magee, M. 2001. The jefferson scale of physician empathy: development and preliminary psychometric data. Educational and Psychological 
Measurement, 61(2), 349-365.

Houbre, B., Tarquinio, C., Thuillier I. 2006. Bullying among students and its consequences on health. European Journal of Psychology of Education, 21 (2), 183-208.

Houbre, B., Tarquinio, C. \& Lanfranchi, J-B. 2010. Expression of self-concept and adjustment against repeated aggressions: the case of a longitudinal study on school bullying. European Journal of Psychology of Education, 25, 105-123.

Jacobs, A.K. 2006. Components of evidence-based interventions for bullying and peer victimization. Issues in Clinical Child Psychology. SpringerLink.

Jolliffe, D. \& Farrington, D.P. 2006. Examining the relationship between low empathy and bullying. Aggressive Behavior. 32, 540-550.

Knafo, A. 2003. Authoritarians, the next generation: values and bullying among adolescent children of authoritarian fathers. Analyses of Social Issues and Public Policy. 3 (1), 199-204.

Knight, P. 1989. Empathy: concept, confusion and consequences in a national curriculum. Oxford Review of Education. 15 (1): 41-53.

Markstrom, C.A., Huey, E., Stiles, B.M., \& Krause, A.L. 2009. Frameworks of caring and helping in adolescence. are empathy, religiosity, and spirituality related constructs? Youth and Society, 20 (10), 1-22.

Olweus, D. 2003. Bully/victim problems in school, Basic facts and an effective intervention programme. Dalam Einarsen, S., Hoel, H., Zapf, D., \& Cooper, C.L. (2003). Bullying and emotional abuse in the workplace, international perspectives in research and practice. New York: Taylor \& Francis.

Papalia D.E, Olds, S.W. Feldman, R.D. 2007. Human development tenth edition. New York: Mc Graw Hill.

Pontzer, D. 2010. A theoretical test of bullying behavior: parenting, personality, and the bully/victim relationship. Journal of Family Violance, 25, 259-273.

Rogers, C.R. 1980. A way of being. America: Houghton Mifflin Company. 
Rousseau, P. 2004. Empathy and compassion: Where have they gone?. American Journal of Hospice and Palliative Medicine ${ }^{\circledR}$, http://ajh.sagepub.com. 21, 331-347.

Salsabiela, W. 2010. Hubungan antara pola asuh authoritative orangtua dengan empati anak pada bystander bullying. Skripsi. Yogyakarta: Fakultas Psikologi UGM.

Santrock, J.W. 2007. Adolescence. Eleventh Edition. Amerika: The McGraw-Hill Companies, Inc.

Sejiwa. 2008. Bullying: mengatasi kekerasan di sekolah dan lingkungan sekitar anak. Jakarta: Grasindo.

Snyder, C.R. \& Lopez, S.J. 2007. Positive psychology: the scientific and practical explorations of human stengths. California: Sage Publications.

Stenberg, R. J. 1999. Perception (cognitive psychology). New York: Holt, Rinehart \& Winston.

Subandi. 2002. Psikoterapi, pendekatan konvensional dan kontemporer. Yogyakarta: Pustaka Pelajar.

Suryabrata, S. 2000. Pengembangan alat ukurpsikologi. Yogyakarta: Penerbit Andi Offset.

Triton, P. B. 2006. SPSS 13.0 terapan: Riset statistik parametrik. Yogyakarta:

Andi Offset.

VandenBos, G.R. 2007. APA dictionary of psychology. Washington, DC: APA.

Walgito, B. 2002. Pengantar psikologi umum. Yogyakarta: Andi Offset.

Wahyuni. 2010. Hubungan antara persepsi pola asuh otoriter dan kemampuan berempati dengan kecenderungan berperilaku bullying pada remaja. Tesis. Yogyakarta : Magister Psikologi UGM.

Wiyani, N.A. 2012. Save our children from school bullying. Yogyakata : Arruzz Media. 